\title{
Investigation of the requirements for the selection of materials for high pressure Turbine blades of conventional turbojet engines
}

\author{
Zhexin Wang, Yuwen Su, Jingpeng Feng \\ National Aerospace University "Kharkiv Aviation Institute" - KhAI University
}

\begin{abstract}
The material selection method is critically evaluated to enable high pressure (HP) turbine blades to deal with in-service damaging phenomena such as creep, low cycle fatigue and high cycle fatigue, oxidation and corrosion. The material selection method is analyzed in order to improve the service life of the aero engine. To increase the turbine inlet temperature, HP turbine blades need improved creep and fatigue resistance. more quality. By the typical working condition of HP turbine blade, using CES Edu Pack (CES) material selection software was used to select suitable materials for HP turbine blade material. Nickel based alloys are selected for HP turbine blades, such as Nickel-Cr-CoMo superalloy.
\end{abstract}

Keywords: Engine, HP Turbine Blades, CES EduPack, Temperature, Cyclic Stresses, Low Density.

The aeroengine is a highly complex and precise thermodynamic machine. As the heart of the aircraft, it is not only the driving force for aircraft flight but also an important driving force for the development of aviation. Every important change in the history of human aviation is related to the technological progress of aero engines. After more than a hundred years of development, aeroengine have developed into mature products with extremely high reliability.

The high pressure (HP) turbine is one of the important components of the aviation gas turbine engine. In order to obtain high performance with small size and lightweight, the main measure is to adopt higher combustion gas turbine inlet temperatures (TIT). When the turbine inlet temperature is increased by $100^{\circ} \mathrm{C}$, (1) the aero-engine thrust-to-weight ratio can be increased by about $10 \%$. The average turbine inlet temperature of the most advanced fourth generation thrust-to-weight ratio of the first-stage engine service condition has reached about $1600^{\circ} \mathrm{C}$. The future generation of fighter engine turbine inlet temperature (2) is expected to reach about $1800{ }^{\circ} \mathrm{C}$.

The aim of the project is to analyze the current selection of turbine blades materials to enable HP turbine blades to deal with in-service damaging phenomena such as creep, low cycle fatigue and high cycle fatigue, thermal shock, oxidation and corrosion. finally, to improve the service life of the aero engine.

Bending, fracture toughness, fatigue, natural frequency and stiffness (3) are important indicators of high-pressure turbine blade materials. The several aspects of turbine blade material requirement are as a fellow.

From the generic beam bending equation:

$$
\frac{M}{I}=\frac{\sigma}{y},
$$

Where: $\sigma$ is the stress at distance $y$ from the neutral axis of the beam; $M$ is the bending moment of the blade; $y$ is the distance from the neutral axis, and $I$ is the second moment of area. For a uniformly distributed load on a cantilever:

$$
M=\frac{w l^{2}}{2},
$$

Where $w$ is the uniformly distributed load in $\mathrm{N} / \mathrm{m} ; l$ is the length of the blade. 


$$
l=\frac{b h^{3}}{12},
$$

Where $h$ is the blade thickness; $b$ is the blade width. Cross-sectional area, $A$ is given by:

$$
A=b h \text {, }
$$

When $y=\frac{h}{2}, \sigma=\sigma_{\max }$ So that:

$$
\begin{gathered}
\frac{I}{y}=\frac{\frac{b h^{3}}{\frac{h}{2}}}{\frac{h}{6}}=\frac{b h^{2}}{6}=\frac{\sqrt{h} A^{\frac{3}{2}}}{6 \sqrt{b}}, \\
\frac{M}{\sigma}=\frac{I}{y}=\frac{\frac{w l^{2}}{2}}{\sigma}=\frac{\sqrt{h} A^{\frac{3}{2}}}{6 \sqrt{b}}, \\
A=\left(\frac{3 w l^{2} \sqrt{b}}{\sigma \sqrt{h}}\right)^{\frac{3}{2}},
\end{gathered}
$$

Mass of the blade, $\mathrm{m}$ is given by:

$$
m=A l \rho,
$$

Where $\rho$ is the material density. Combine the equation 7 and equation 8 :

$$
m=\left(\frac{3 w l^{2} \sqrt{b}}{\sqrt{h}}\right)^{\frac{3}{2}} l \frac{\rho}{\left(\sigma_{y}\right)^{\frac{2}{3}}},
$$

Where $\sigma_{y}$ is the yield strength. Therefore, to minimize mass, the material index $\frac{\left(\sigma_{y}\right)^{\frac{2}{3}}}{\rho}$ should be maximized. Assuming that the blade follows the equation of a center cracked plate with a very large width.

$$
K_{I C}=\sigma(\pi a)^{\frac{1}{2}}
$$

Where $K_{I C}$ is the fracture toughness; $\sigma$ is the applied stress; $a$ is a small crack size. Cross-sectional Area, $A$ is given by:

$$
A=\frac{w l}{\sigma}
$$

Where $w l$ is the total load on the blade, Combine the equation 10 and equation 11.

$$
\begin{gathered}
K_{I C}=\frac{w l}{A}(\pi a)^{\frac{1}{2}}, m=A l \rho \\
m=w l^{2}(\pi a)^{\frac{1}{2}}\left(\frac{\rho}{K_{I C}}\right),
\end{gathered}
$$


To optimize performance indices, to minimize mass $(m), \frac{K_{I C}}{\rho}$ should be maximized.

Fatigue strength endurance limit $\sigma_{e}$ should be more than stress $\sigma$, and $m=A l \rho$ Hence,

$$
\begin{gathered}
\frac{w l}{A} \leq \sigma_{e}, \\
m=w l^{2} \frac{\rho}{\sigma_{e}},
\end{gathered}
$$

To optimize performance indices, to minimize mass $(m), \frac{\sigma_{e}}{\rho}$ should be maximized.

To optimize performance indices, Natural Frequency should be maximized. The natural frequency (4) of a body is given by:

$$
f=\frac{1}{2 \pi}\left(\frac{K}{m}\right)^{\frac{1}{2}}
$$

Where $K$ is the stiffness constant and is given by:

$$
K=\frac{A E}{l},
$$

Combine the equation 16 and equation 17:

$$
f=\frac{1}{2 \pi}\left(\frac{E}{\rho}\right)^{\frac{1}{2}}
$$

To maximize natural frequency, $\left(\frac{E}{\rho}\right)^{\frac{1}{2}}$ should be maximized.

To optimize performance indices, stiffness should be maximized. The stiffness of a beam (4) is given by:

$$
S=\frac{F}{Y},
$$

Where $S$ is the stiffness of the material, $F$ is the load applied, $\Delta$ is the deflection.

$$
\begin{gathered}
S=\frac{w l}{\left(\frac{w l^{3}}{8 E I}\right)}=\frac{8 E I}{l^{2}}, \\
I=\frac{b h^{3}}{12}, \\
S=\frac{8 E b h^{3}}{12 l^{2}}, \\
m=A l \rho, A=b h
\end{gathered}
$$




$$
m=\left(\frac{3 S b}{2 h}\right)^{\frac{1}{2}} l\left(\frac{\rho}{E^{\frac{1}{2}}}\right)
$$

To optimize performance indices, to minimize mass $(m), \frac{E^{\frac{1}{2}}}{\rho}$ should be maximized.

In conclusion, to resist bending at minimum mass, the material index $\frac{\left(\sigma_{y}\right)^{\frac{2}{3}}}{\rho}$ should be maximized. To maximize fracture toughness while keeping mass to its minimum, $\frac{K_{I C}}{\rho}$ should be maximized. To resist fatigue at minimum mass, the $\frac{\sigma_{e}}{\rho}$ should be maximized. It was also derived that to maximize the natural frequency, $\left(\frac{E}{\rho}\right)^{\frac{1}{2}}$ should be maximized. It was derived that to maximize specific stiffness, $\frac{E^{\frac{1}{2}}}{\rho}$ should be maximized.

The limits are set to the maximin working temperature and fracture toughness. The maximin front blade temperature is $1320 \mathrm{~K}$ shown in Table 3. Fracture toughness is one of the most important factors that determine the longevity of the HP turbine blade under such severe conditions. Therefore, a minimum value of $30 \mathrm{MPa} \cdot m^{0.5}$ was used to filter off materials with fracture toughness below this value as presented in Figure 1.

A graph of specific elastic modulus vs specific yield strength in bending was plotted to determine a set of materials that has this property as shown in Figure 2.

A graph of maximum service temperature against price was plotted to determine a set of materials that have this property as shown in Figure 3.

It can be found from Fig. 1, 2, 3 that there are many kinds of metal materials suitable for HP turbine blades, including stainless steel, Nickel-based alloy, Molybdenum alloy.

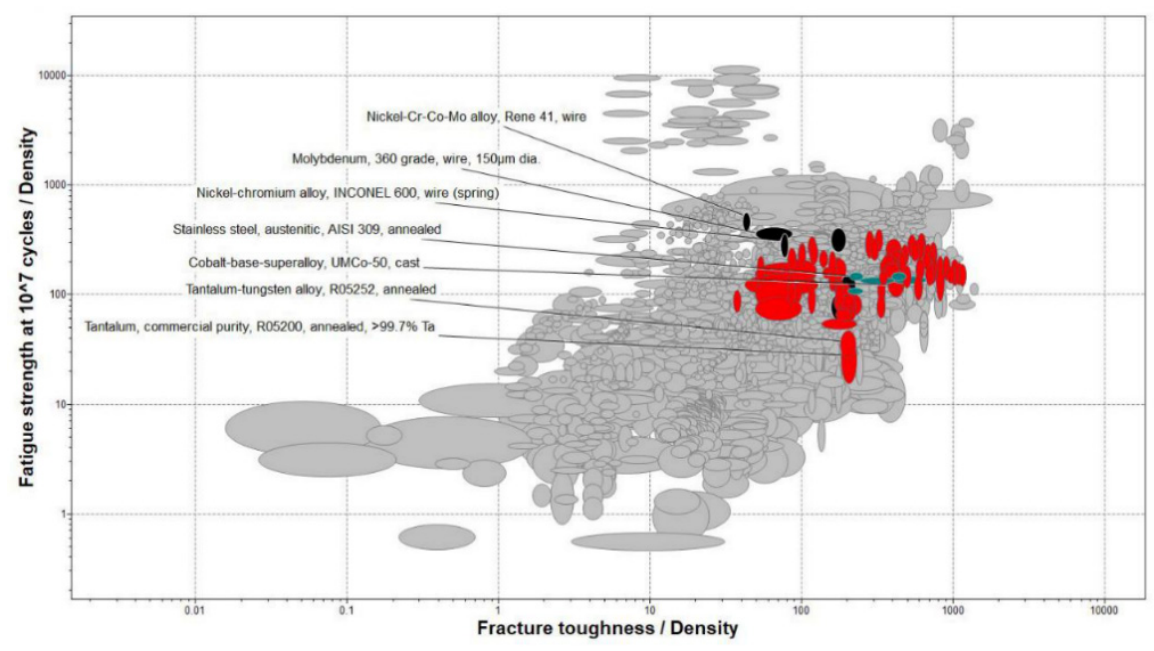

Fig. 1. Graph of specific fatigue strength against specific fracture toughness 


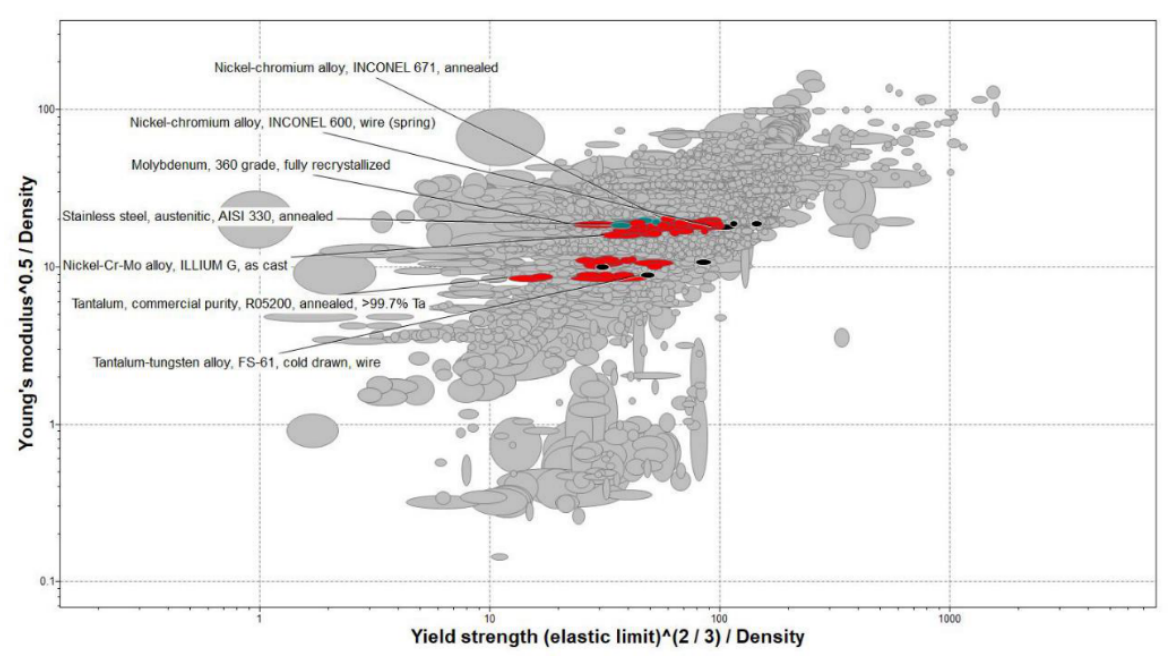

Fig. 2. Graph of elastic modulus against yield strength with respect to density in bending

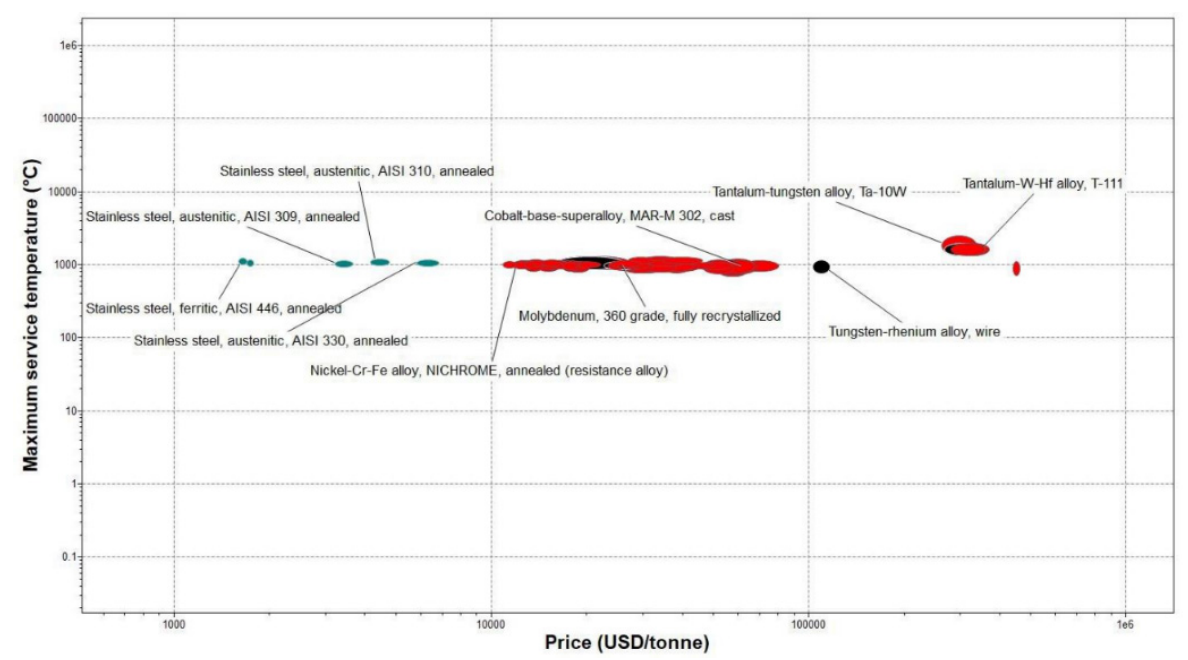

Fig. 3. Maximum service temperature against the price

The material suitability ranking chart under three different constraints. The three rank methods are rank by Fracture Toughness and Fatigue, rank by Bending and Stiffness, and rank by Price. These three different rank standards respectively correspond to the results of Fig. 1, 2, 3. There are three different kinds of materials that can be considered apply on HP turbine blades which are stainless steel, Nickel-based alloy, and Molybdenum alloy.

Stainless steel, Nickel-based alloy, and Molybdenum alloy have different application fields because of their different material properties. Molybdenum alloy (5) has shortcomings such as lowtemperature brittleness, welding brittleness, and high-temperature oxidation, so its development is limited. Stainless steel has poor low-cycle fatigue and high-cycle fatigue performance, and poor creep resistance. The nickel-based alloy (6) has high strength, good oxidation and good corrosion resistance. It is often used in the manufacture of engine turbine blades, but the low angle boundary and recrystallization are cannot completely be eliminated. In conclusion, using Nickel-based alloy on HP turbine blade, such as Nickel-Cr-Co-Mo Superalloy.

In order to develop more efficient aero engines, ceramic matrix composite (CMC) materials can be used for HP turbine blades in the future. As one of the most typical ceramic matrix composite materials, fiber reinforced ceramic matrix composites is used to add fibers to ceramics to greatly increase the strength, improve reduce brittleness, and increase the maximum service use temperature. 
The improvement in fracture toughness specially to make CMCs insensitive to crack propagation, overcoming the fatal shortcomings of general conventional ceramics such as high brittleness and poor reliability.

\title{
Conclusion
}

To improve HP turbine blade quality, the material index $\frac{\left(\sigma_{y}\right)^{\frac{2}{3}}}{\rho}, \frac{K_{I C}}{\rho}, \frac{\sigma_{e}}{\rho}, \frac{E^{\frac{1}{2}}}{\rho},\left(\frac{E}{\rho}\right)^{\frac{1}{2}}$ should be maximized. Using CES software for material screening get that the Nickel-based alloy is currently most suitable on modern HP turbine blade, such as Nickel-Cr-Co-Mo superalloy.

\section{References}

1. Chen R, Wang L, Li J. Review and prospect on developments of cast superalloys. Hangkong Cailiao Xuebao (Journal of Aeronautical Materials) (China) (China) 2000;20:55-61.

2. Guan P, Yan-Ting A, Cheng-Wei F. An Enhanced Flow-Thermo-Structural Modeling and Validation for the Integrated Analysis of a Film Cooling Nozzle Guide Vane. Energies 2019 02;12(14).

3. I.A. Essienubong. Material Selection for High Pressure (HP) Turbine Blade of Conventional Turbojet Engines. Journal of American Journal of Mechanical and Industrial Engineering 2016;1(1): p.1-9.

4. Ashby M. F. Materials Selection in Mechanical Design. Oxford: Pergamon Press 1992p.45-49.

5. Wang Z, Xing Z, Wang H, Shan D. Research progress in influence of non-metallic inclusion characteristics on fatigue properties of iron and steel materials. Cailiao Gongcheng = Journal of Materials Engineering 2020 05;48(5):1

6. Anand B, Ayush M, Nitin K, Singh SK. Influence of material modeling on warm forming behavior of nickel based super alloy. International Journal of Material Forming 2020;13(3):445-465

\section{Исследование требований к выбору материалов для высокого давления Лопатки турбины обычных турбореактивных двигателей}

\author{
Чжесинь Ван, Юйвень Су, Фэн Цзинпэн
}

Аннотация. Для того, чтобы лопатки турбин высокого давления могли справляться с такими повреждающими явлениями, как ползучесть, малочикловая и многоцикловая усталости, окисление и коррозия, необходимо критически оценивать метод выбора материала. Анализ метода выбора материала производится с иелью увеличения срока службы авиадвигателя. Для повышения температуры на входе в турбину лопаткам турбины ВД требуется повышенное сопротивление ползучести и усталости. Учитывая типичные рабочие условия лопатки турбины ВД, подходящче материалы были подобраны с помощью программного обеспечения для выбора материала CES Edu Pack (CES). Для лопаток турбины ВД было предложено использовать сплавы на основе никеля, такие как суперсплав никель-хром-кобальт-молибден.

Ключевые слова: Турбореактивный двигатель, лопатки турбин высокого давления, CES EduРack, температурные, ичилические напряжения, низкая плотность.

\section{Дослідження вимог до вибору матеріалів для високого тиску Лопатки тур- біни звичайних турбореактивних двигунів}

\section{Чжесінь Ван, Юйвень Су, Фен Цзінпен}

\begin{abstract}
Анотація. Для того, щуоб лопатки турбін високого тиску могли справлятися з такими пошкоджувальними явищзами, як повзучість, малоциклова і багатоциклова втоми, окислення $і$ корозія, необхідно критично оцінювати метод вибору матеріалу. Аналіз методу вибору матеріалу проводиться з метою збільшення терміну служби авіадвигуна. Для підвищення температури на вході в турбіну лопаткам турбіни ВТ потрібен підвищений опір повзучості і втоми. 3 огляду на типові робочі умови лопатки турбіни ВТ, відповідні матеріали були підібрані за допомогою програмного забезпечення для вибору матеріалу CES Edu Pack (CES). Для лопаток турбіни ВТ було запропоновано використовувати сплави на основі нікелю, такі як суперсплав нікель-хром-кобальт-молібден. Ключові слова: турбореактивний двигун, лопатки турбін високого тиску, CES EduРасk, температурні, циклічні напруження, низька щзільність.
\end{abstract}

